\title{
Assessment of Current Status of Invasive Aquatic Plants in Louisiana
}

\author{
F. A. Anifowose1, V. I. Fagorite ${ }^{2}$ \\ ${ }^{1}$ Department of Environmental Science, University of Louisiana at Lafayette, Lafayette, LA, USA \\ ${ }^{2}$ Department of Geology, Federal University of Technology Owerri, Owerri, Nigeria \\ Email: ayorite@yahoo.com
}

How to cite this paper: Anifowose, F.A. and Fagorite, V.I. (2020) Assessment of Current Status of Invasive Aquatic Plants in Louisiana. Open Access Library Journal, 7: e6429.

https://doi.org/10.4236/oalib.1106429

Received: May 14, 2020

Accepted: June 2, 2020

Published: June 5, 2020

Copyright $\odot 2020$ by author(s) and Open Access Library Inc.

This work is licensed under the Creative Commons Attribution International License (CC BY 4.0).

http://creativecommons.org/licenses/by/4.0/

(c) (i) Open Access

\begin{abstract}
Invasive aquatic plants include plants and algae that grow partially or entirely submerged in water. The United States Department of Agriculture Early Detection and Distribution Mapping system (USDA EDD Maps) was used to collate number of positive observations for all the aquatic invasive species in Louisiana. United States Geological Survey Non-indigenous aquatic species (USGS NAS) database was used to collate each species years of first and last observations and number of affected HUC in Louisiana State. The collated data were recorded and formatted using Excel spreadsheet. The analyses of the data were done using Excel software to generate different charts. The main objective of this paper was to evaluate the current impacts and management of invasive aquatic plants in Louisiana and also to assess whether several resources expended on eradication of these plants have resulted in improved water quality of the State. From the collated data from USGS and USDA EMM Maps, it shows earliest date of observation of invasive aquatic plant in Louisiana from 1884. Common Water hyacinth has the highest number of observations to date. About 41 hydrological unit areas have been affected by infestation of Alligator weed as well. The continuous spread of invasive aquatic plants in Louisiana could be due to favorable weather conditions, excessive nutrients runoff from agricultural practices, reduction of government allocated funds, and uncooperative human community. The current State of Louisiana statewide management plan has done little in the control of the major notorious aquatic plant invaders such as giant Salvinia and water hyacinth. Although, several biological, chemical and mechanical management controls are being implemented yearly, there is a need for interagency collaboration, establishment of efficient State database, and stricter laws on voluntary anthropogenic activities such as sales of invasive weeds as ornamental plants and smuggling of unwanted species through the waterways into the states.
\end{abstract}




\section{Subject Areas}

Environmental Sciences

\section{Keywords}

Invasive Aquatic Plants, Water Hyacinth, Giant Salvinia, Alligator Weed, Louisiana

\section{Introduction}

In 1990, the Federal government enacted a non-indigenous aquatic nuisance prevention and control act to compact the effect of invasive species in the United States of America. Many organizations and agencies were created to specifically tackle problems that result from the nuisance invaders. In 2005, Governor Mike Foster of Louisiana formed a 29-member non-indigenous aquatic species advisory task force from public and government entities. This task force designed a management master plan for the state and several agencies were later empowered to carry out control, management and eradication of aquatic invasive species when possible. Tulane and Xavier University Center for Bioenvironmental Research, Louisiana State University AgCenter, Louisiana Sea Grant, United States Army Corp of Engineers, and Louisiana Department of Wildlife and Fisheries are among the organizations that have been assessing and controlling the impacts of aquatic invasive plants in the state. There is a need to review what has been done by these agencies and assess the current trend of aquatic invasive plants in Louisiana State. The southeastern part of the country has the highest diversity of habitat, with 47 percent of the nation's wetlands, 78 percent of its coastal marshes, and over 70 major river basins. The warm climate and ample rainfall help support many of the world's plants and animals. The abundant waterways open the region to non-native species more than any other regions of the country.

Invasive species are non-native aquatic plants and other organisms whose introduction can cause adverse impacts on environment, economy and human health. These invaders have been introduced into the Louisiana coastal waterway through shipping vessels, animal and human immigrations. Ecologically, they make the waterways to have unsightly aesthetics, serve as vector habitat, alter food web relationships, and disrupt recreation, flood control, and hydroelectricity. Toxicity of the surface waters can result in fish-kills, and health hazards for humans.

Invasive aquatic plants include plants and algae that grow partially or entirely submerged in water (Figure 1). This includes plants that are rooted in the sediment with part or all of the plant underwater, as well as plants that float freely without contacting the sediment [1] [2]. Aquatic plants may invade both marine and freshwater environments, including habitats such as wetlands, lakes, rivers, 
estuaries, coastal zones, irrigation systems, hydroelectric systems, and aquaculture facilities [1]. These aquatic invasive plants have several traits such as short reproductive cycle, high genetic variability, ability to thrive in a wide range of environments and ability to aggressively compete to displace other plants from the coastal waterway (Figure 2).

Within the coastal zone of Louisiana, common Salvinia (Salvinia minima), Eurasian watermilfoil (Myriophyllum spicatum), giant Salvinia (Salvinia molesta), hydrilla (Hydrilla verticillata), and water hyacinth (Eichhornia crassipes) are

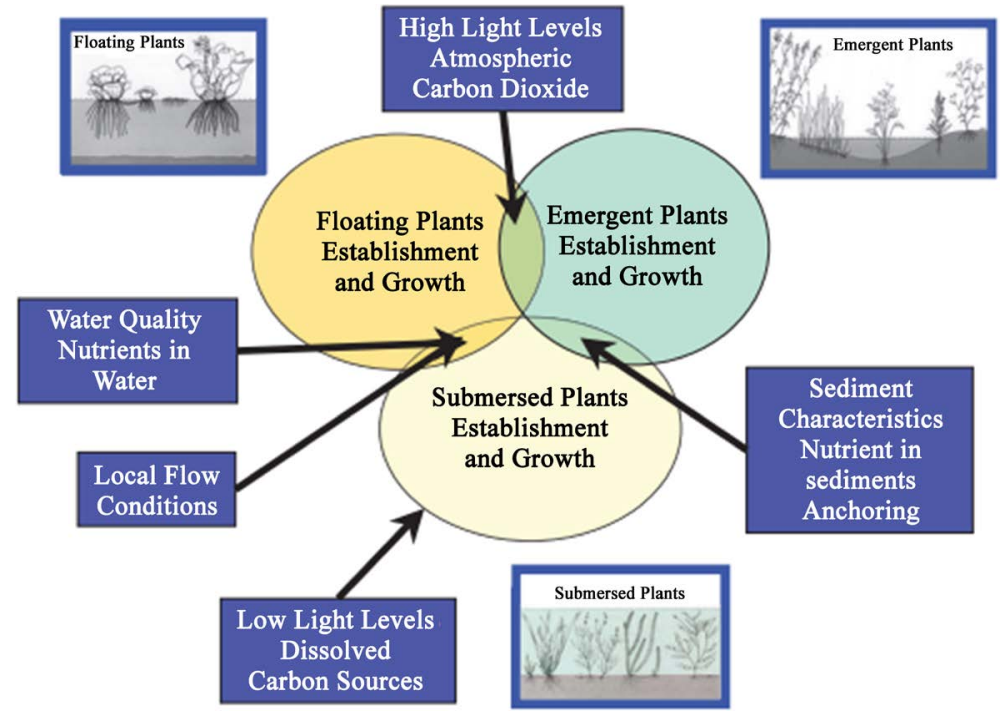

Figure 1. Diagrammatic picture of different types of aquatic plants.

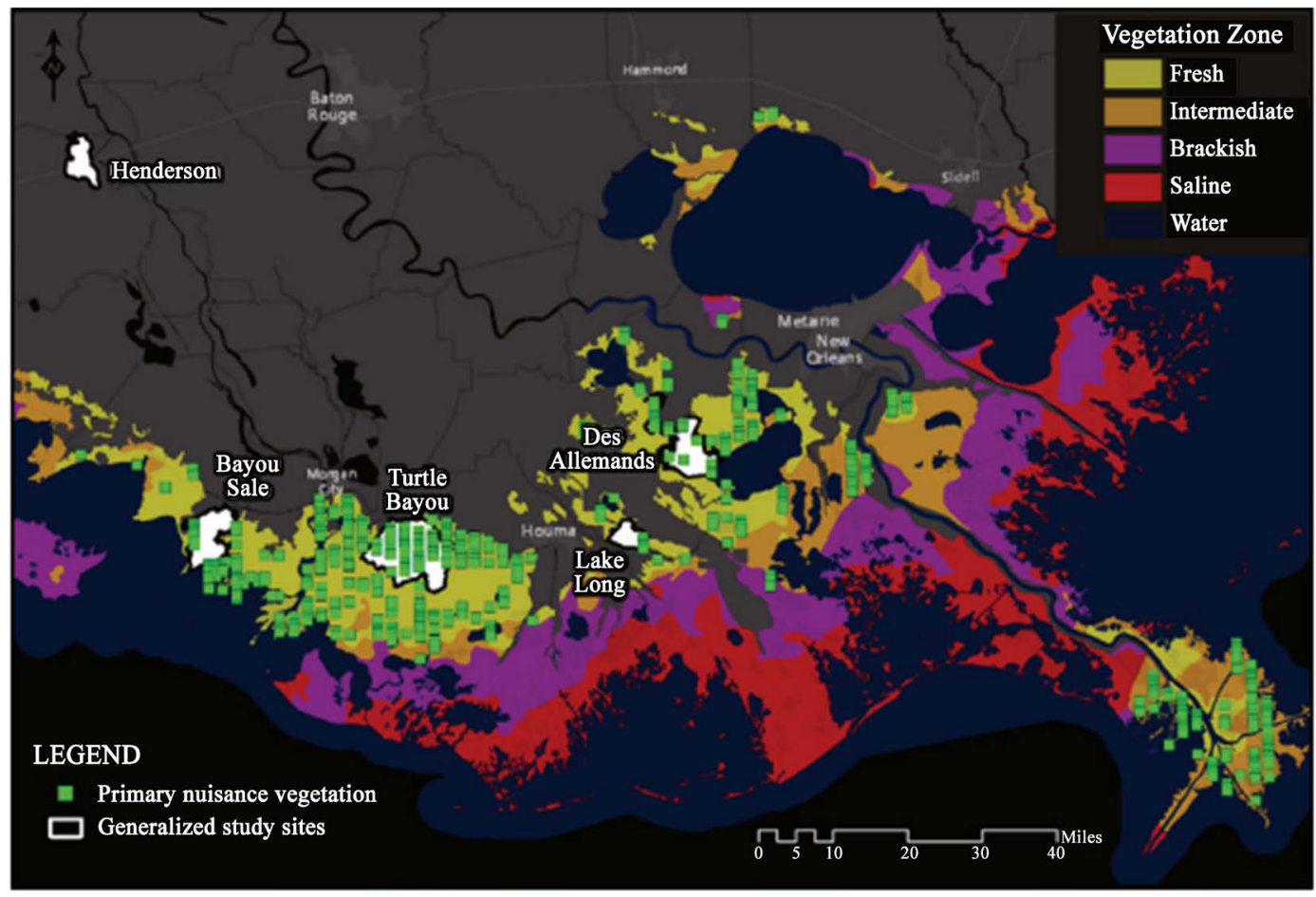

Figure 2. Surveys of species in coastal Louisiana (After [3]). 
the primary nuisance invasive species of concern. Species such as sedges (Carex spp.), alligator weed (Alternanthera philoxeroides), pennywort (Hydrocotyle ranunculoides), and primrose (Ludwigia spp.) present minimal.

Aquatic invasive plants of Louisiana are classified into the 3 categories by USGS nonindigenous aquatic species program. The categories are:

1) Extensively Established Species

2) Locally Established Species and

3) Potential Arrivals

Extensively established species are those found in 8 or more of the 13 drainage basins of Louisiana. Locally Established Species are those found in 3 to 7 drainage basins, and Potential Arrivals are plants found in 2 or fewer drainages.

Some examples of Extensively Established Species are as follows: Water Hyacinth (Eichhornia crassipes), introduced in 1885 at world's industrial and cotton centennial exposition in New Orleans, Louisiana as an ornamental plant (Figure 3). A native of South American known for its beautiful flowers can be found in almost all the drainage basin of the state. Parrot feather (Myriophyllumaquaticum), a submerged aquatic plant from Amazon River basin of South America, was first discovered in the United States in 1890 at a Washington, D.C pond. It is a popular aquatic gardens plant that probably escaped cultivation through aquarium deliveries into open water bodies. Hydrilla (Hydrilla verticillata), a rooted, aquatic weed from Asia that inhabits both deep and shallow waters. First observation in Louisiana was in 1973. It sometimes made several waterbodies to be unusable for aquatic recreation, for example, Spring Bayou Wildlife Management

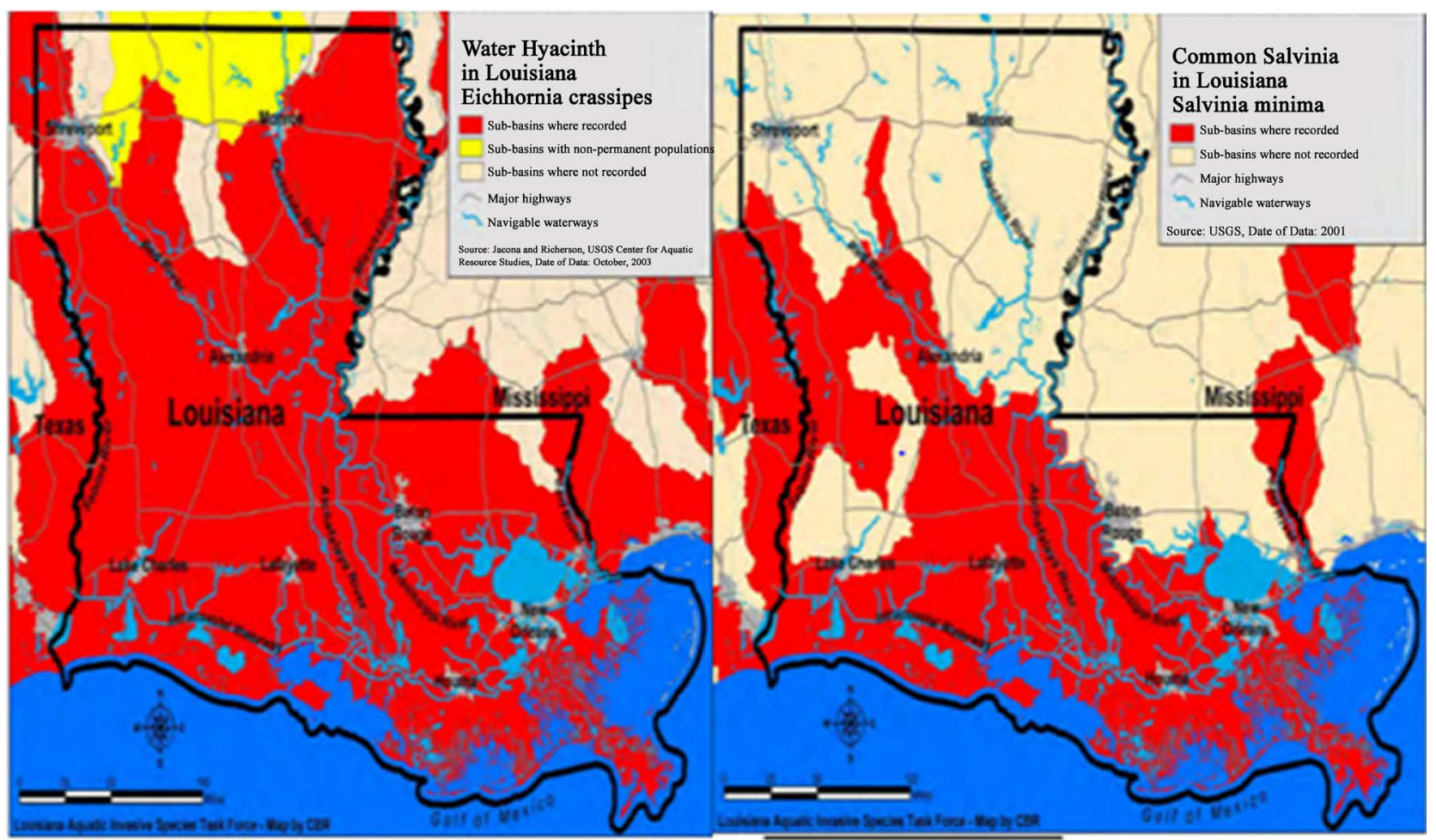

Figure 3. Map of water hyacinth and common Salvinia coverage in Louisiana (After [3]). 
Area and Henderson Lake in the Atchafalaya Basin has experienced excessive growth of hydrilla plant. Brazilian Waterweed (Egeria densa), introduced to Louisiana in 1960, Brazilian waterweed is a popular aquarium plant because of its oxygenating properties. Some researchers believe this oxygenator plant can be used in control of mosquito larvae. Eurasian Watermilfoil (Myriophyllum spicatum), first observation in Louisiana was in 1973, it is unique because of its ability to tolerate both fresh and brackish waters. Its rapid spread throughout the state could be due to its use as packing material for bait worms sold to fishermen. Water Lettuce (Pistia stratiotes), a perennial floating plant from Africa was first observed in the state in 1958. The plant is listed on Federal Noxious Weed List, but it can still be purchased through aquarium suppliers and on the Internet. Common Salvinia (Salvinia minima), is a floating fern from central and southern America. It was first recorded in Louisiana in 1980 in the Bayou Teche area of St. Mary Parish, and has since been constituting a major nuisance throughout the state especially for farmers. Common salvinia forms thick mats on the water surface and can be up to 25 centimeters deep in some cases (Figure 3 ).

Locally Established Species example is Giant Salvinia (Salvinia molesta), first appeared in Louisiana in 1998 in the Toledo Bend Reservoir. Since then, it expanded into at least 43 locations throughout Southern Louisiana. It is a free-floating fern that reproduces quickly under ideal conditions such as nutrient availability and warmer temperatures. In Cameron Parish, Louisiana, giant salvinia posed a public health threat because it blocked the operation of floodgates [4]. An example of Potential Arrival Species is Purple Loosestrife (Lythrum salicaria), is an invasive plant introduced from Europe in the 1800 s as an ornamental plant. A single mature loosestrife plant can produce an estimated 3 million seeds annually. These seeds are prone to wind, animal, and water dispersal. It is an easy-to-grow plant with attractive purplish-magenta flowers that can be purchased in many plant nurseries, and garden stores.

Several management plans have been developed since enactment of laws governing invasive aquatic plants and establishments of organizations that will implement these laws. A current assessment should be able to answer pertinent questions such as:

1) Have there been changes in the range of a particular species expansion since first observation?

2) Have new invasive species arrived in Louisiana since the 2005 statewide management plan?

3) Have financial and ecological costs of the impact of certain species increased or decreased?

4) And if the State waterways and water quality are better than previous years?

Hence, the main objective of this paper is to evaluate the current impacts and management of invasive aquatic plants in Louisiana and also to assess whether several resources expended on eradication of these plants have resulted in improved water quality of the State. 


\section{Methodology}

United States Department of Agriculture Early Detection and Distribution Mapping system (USDA EDD Maps) was used to collate number of positive observations for all the aquatic invasive species in Louisiana. United States Geological Survey Non-indigenous aquatic species (USGS NAS) database was used to collate each species years of first and last observations and number of affected HUC in Louisiana State [5]. The collated data were recorded and formatted using Excel spreadsheet. The analyses of the data were done using Excel software to generate different charts. Also, reports from 2005 Louisiana Statewide management plan, 2015 reports of Michigan Lake and Stream Association and 2018 Army Corp of Engineers on Aquatic Plant Control Research Program of coastal Louisiana were used to support data from USDA and USGS databases.

\section{Results and Discussion}

The collated data from USGS and USDA EMM Maps shows earliest date of observation of invasive aquatic plant in Louisiana from 1884 as shown in Table 1 and Figure 6 combo chart. Common Water hyacinth has the highest number of observations till date as shown by Figure 4. About 41 hydrological unit areas have been affected by infestation of Alligator weed as depicted by Figure 5 .

Over 30 invasive aquatic plants species have been documented in the state of Louisiana (Table 1). Some of them have been eradicated after their first observation. Majority of them despite being controlled are spreading around the state at an alarming rate. There is progressive increase in the number of observed locations, HUC and specie establishment from the 2005 report of Louisiana Invasive Aquatic species task force and 2018 report of US Army Corp of Engineers (Figure 4 and Figure 5). According to combo chart of Figure 6, only feathered mosquito fern and crested floating heart species have achieved a form of eradication with no new observed locations. Common water hyacinth remains the oldest and most widely spread invasive aquatic plant in Louisiana as evidenced by Figures 4-6. Alligator weed infestation in $41 \mathrm{HUC}$ of Louisiana made it the highest among all other species. Recently, giant Salvinia aggressive nature is causing a widespread in the State waterways within the short time of introduction. Several measures developed to manage the aquatic invasive plants by the state include: chemical, physical and biological control.

The Louisiana Department of Wildlife and Fisheries performs aquatic vegetation control through the use of 2, 4-D applications against water hyacinth, followed by fluridone to control hydrilla, and combinations of glyphosate and diquat on common Salvinia as a form of chemical control [6]. For biological control of giant Salvinia in Louisiana, USDA APHIS, LDWF, and LSU AgCenter are working together to develop effective Cyrtobagous salviniae that can control the growth of Salvinia molesta throughout the entire season of the year [1]. USDA APHIS Center for Plant Health Science and Technology laboratories will supply biological control agents. Tests began in June 2002 at Jean Lafitte National His- 
torical Park and Preserve and have since been a major control of giant Salvinia.

Physical control involves use of mechanical harvesting and hydrologic drawdown. Mechanical harvesting typically uses equipment to remove small populations of

Table 1. Showing the collated aquatic invasive species in Louisiana.

\begin{tabular}{|c|c|c|c|c|}
\hline Common Name of Plants & $\begin{array}{l}\text { Observations } \\
\text { in Louisiana }\end{array}$ & $\begin{array}{c}\text { No of affected } \\
\text { HUC }\end{array}$ & $\begin{array}{c}\text { Year of } 1^{\text {st }} \mathrm{Ob}- \\
\text { servation }\end{array}$ & $\begin{array}{l}\text { Year of Last } \\
\text { Observation }\end{array}$ \\
\hline Common Water Hyacinth & 266 & 38 & 1915 & 2019 \\
\hline Aligator Weed & 229 & 41 & 1946 & 2018 \\
\hline Parrot Feather & 157 & 31 & 1915 & 2019 \\
\hline Dotted Duckweed & 140 & 36 & 1961 & 2000 \\
\hline Hydrilla & 115 & 27 & 1973 & 2015 \\
\hline Water Lettuce & 99 & 17 & 1958 & 2016 \\
\hline Braizilian Waterweed & 88 & 16 & 1960 & 1993 \\
\hline Torpedograss & 75 & & & \\
\hline Eurasian water milfoil & 69 & 9 & 1979 & 2016 \\
\hline Creeping Waterprimrose & 54 & 21 & 1986 & 2015 \\
\hline Europe Common Reed & 52 & & & \\
\hline Yellow Iris & 46 & 7 & 1972 & 1993 \\
\hline American Frogbit & 45 & & & \\
\hline Fragrant Waterlily & 44 & & & \\
\hline Giant Salvinia & 42 & 24 & 1998 & 2019 \\
\hline Carolina Fernwort & 42 & & & \\
\hline Water Hyancinth & 30 & 38 & 1884 & 2018 \\
\hline Duck-Lettuce & 30 & 9 & 1939 & 2007 \\
\hline Two leaf Watermil Foil & 30 & & & \\
\hline Purple Loosestrife & 21 & & & \\
\hline Brittle Leaf Naiad & 20 & & & \\
\hline Sessile Joyweed & 20 & & & \\
\hline Narrow-leaved Cattail & 15 & 3 & 1984 & 2015 \\
\hline Curly Leaved Pondweed & 10 & 1 & 1949 & 2015 \\
\hline Deeprooted Sedge & 9 & 4 & 2007 & 2015 \\
\hline Yellow Fieldcress & 9 & 3 & 1972 & 2008 \\
\hline Common Reed & 4 & & & \\
\hline Crested Floating Heart & 2 & 1 & 2012 & 2018 \\
\hline White Eqyptian Lotus & 2 & & & \\
\hline Yellow Floating Heart & 1 & 1 & 1899 & 1899 \\
\hline Feathered Mosquito Fern & 1 & 1 & 2009 & 2009 \\
\hline Common Salvinia & & 20 & 1980 & 2018 \\
\hline
\end{tabular}




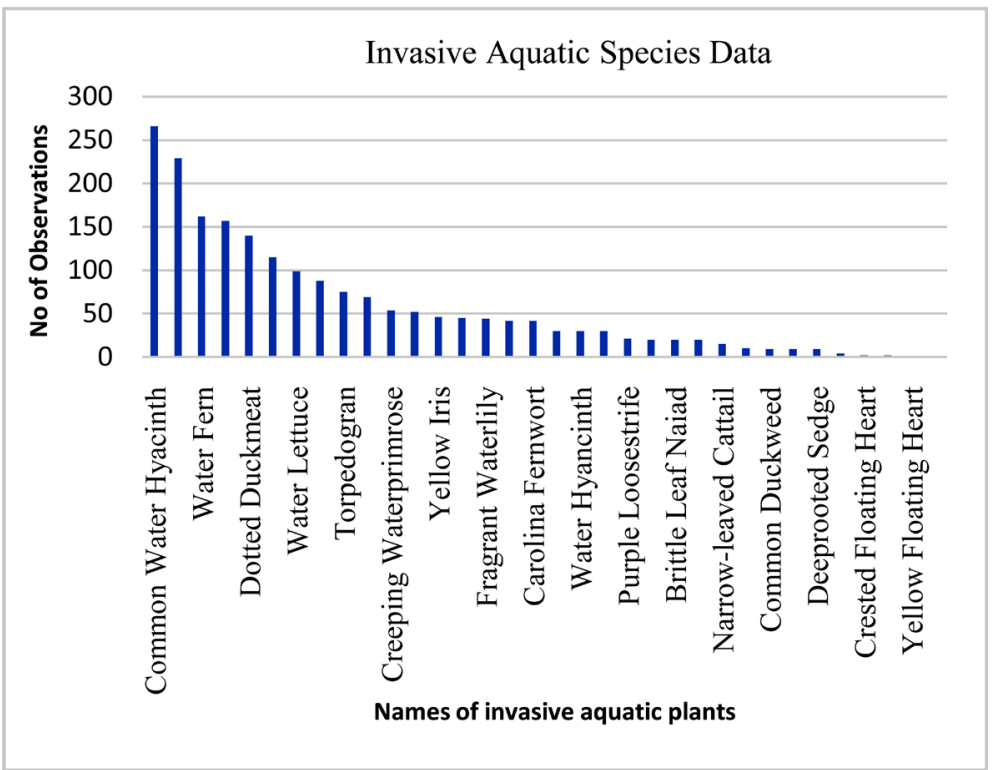

Figure 4. Column chart for observed locations of aquatic invasive plants in Louisiana.

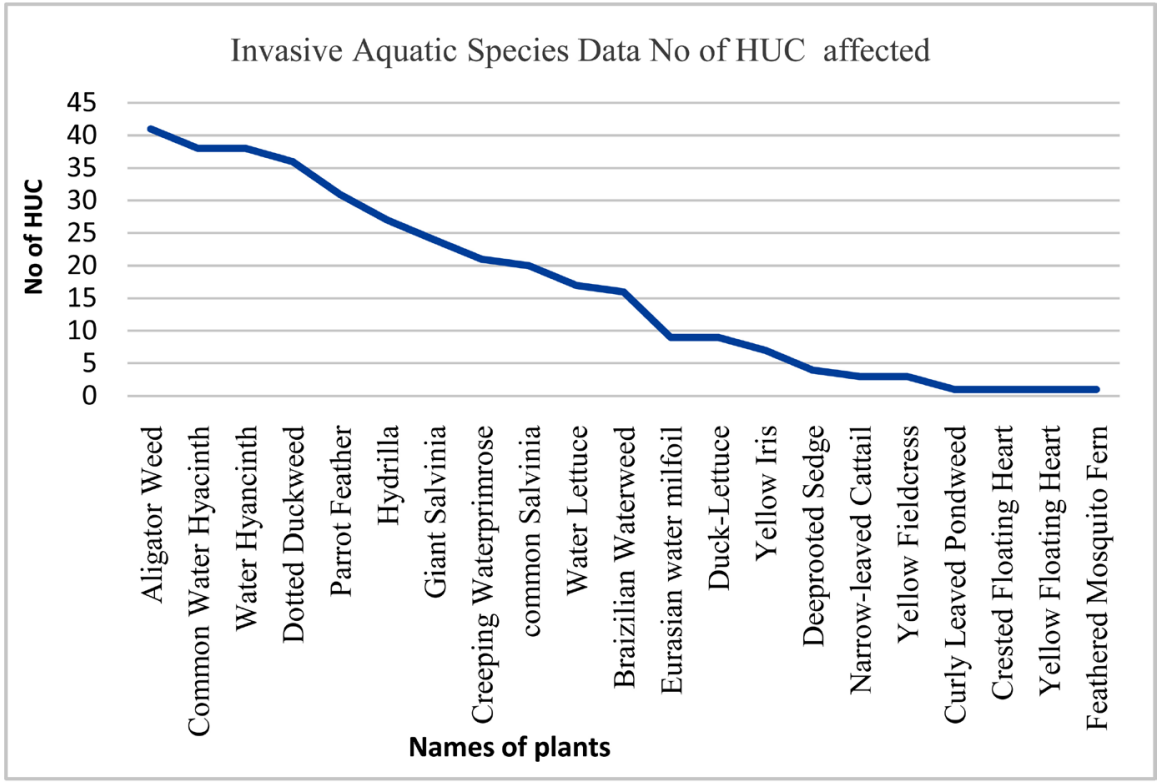

Figure 5. Line graph of affected Louisiana HUC in 2019.

nuisance plants while hydrological drawdown has been used on water hyacinth at Lake Henderson. Recent innovation in the management of invasive aquatic plants is the integrated pest management (IPM), an approach correct identification of the invasive or nuisance plants, identifying desired vegetation to achieve fish and wildlife habitat goals, establishing tolerable levels of any single plant species, including target nuisance plants, making decisions based on site-specific information, the use of the ecosystem, watershed, and cost-benefit perspectives to determine long-term management strategies, developing an on-going system of integrated control methods that include mechanical, cultural, biological, and chemical treatments as needed, educating local managers and the public about 


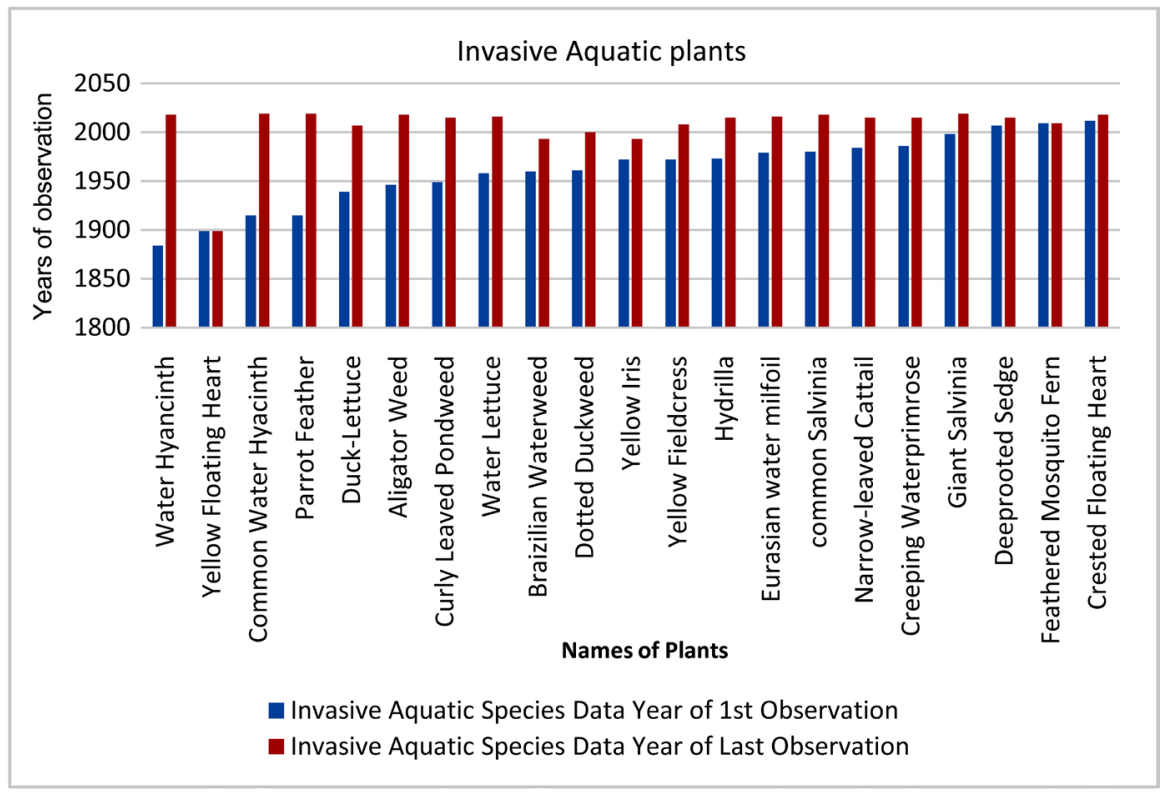

Figure 6. Showing combo chart of first and last years of observation of different invasive aquatic plants.

the importance of protecting water resources from invasive weeds to maintain healthy water quality and fish and wildlife habitat assessing results of invasive weed control programs and re-evaluating management options [7].

\section{Conclusions and Recommendations}

The continuous spread of invasive aquatic plants in Louisiana could be due to favorable weather conditions, excessive nutrients runoff from agricultural practices, reduction of government allocated funds, and uncooperative human community. It is very difficult to eradicate an invasive species once it has been established in a particular location. The current State of Louisiana statewide management plan has done little in the control of the major notorious aquatic plant invaders such as giant Salvinia and water hyacinth. Although, several biological, chemical and mechanical management controls are being implemented yearly, there is a need for interagency collaboration, establishment of efficient State database, and stricter laws on voluntary anthropogenic activities such as sales of invasive weeds as ornamental plants and smuggling of unwanted species through the waterways into the states. The state government should place emphasis and fund universities and organizations studying control of invasive aquatic plants as much as water quality funding because if the surface waters can be rid of the plants it will directly improve the standard qualities of the coastal Louisiana surface waters.

In the course of this research, there are some discrepancies between species listed as aquatic invasive plants from different agencies. Louisiana department of wildlife and fishes needs an accessible database for the State. Laws pertaining to importation and sale of invasive plant through nursery and garden sales should 
be strengthened and enforced. Federal and State border personnel should inspect foreign arriving vessels, cargo, and cruise ship passengers at all Louisiana maritime docks for exotic plants. Above all, more money should be invested in the research of eradication and controls of invasive aquatic plants.

\section{Acknowledgements}

First, I am most grateful to God for his grace, love, and inspiration. To Professor Poudel, D., for his assistance during the course of this study. Finally, I appreciate my gifted and brilliant babies, Deborah and David Anifowose.

\section{Conflicts of Interest}

The authors declare no conflicts of interest regarding the publication of this paper.

\section{References}

[1] Anderson, L. (2011) Freshwater Plants and Seaweeds. In: Simberloff, D. and Rejmanek, M., Eds., Encyclopedia of Biological Invasions, University of California Press, Berkeley.

[2] Smith, J.E. (2011) Algae. In: Simberloff, D. and Rejmanek, M., Eds., Encyclopedia of Biological Invasions, University of California Press, Berkeley.

[3] Alysia, R. and Meaux, S. (2010) Invasive Species Map. Center for Bioenvironmental Research. http://is.cbr.tulane.edu/solutions.html

[4] Kravitz, A.R., Campanella, R. and Schiavinato, L. (2005) State Management Plan for Aquatic Invasive Species in Louisiana. Center for Environment Research at Tulane and Xavier Universities, New Orleans.

[5] Wersal, R., Baker, E., Larson, J., Dettloff, K., Fusaro, A.J., Thayer, D.D. and Pfingsten, I.A. (2019) Myriophyllum aquaticum (Vell.) Verdc. U.S. Geological Survey, Nonindigenous Aquatic Species Database. https://nas.er.usgs.gov/queries/factsheet.aspx?SpeciesID $=235$

[6] Suir, G.M., Suir, K.J. and Sapkota, S. (2018) Use of Remote Sensing to Detect and Predict Aquatic Nuisance Vegetation Growth in Coastal Louisiana. United States Army Corp of Engineers, Washington DC. https://doi.org/10.21079/11681/26649

[7] Davidson, A. (2015) Invasive Aquatic Plant Control and Management Guide: A Summary of Management Options and Service Providers. Michigan Lake and Stream Associations, Stanton. 